\title{
Takotsubo cardiomyopathy after severe emotional stress: a case report and a brief literature review
}

\author{
Lea Skorup*, David Gobić ${ }^{1 *}$ Vjekoslav Tomulić², Davorka Lulić', Teodora Zaninović Jurjević², Luka \\ Zaputović ${ }^{2}$, Alen Ružićc \\ ${ }^{1}$ Department of Emergency Medicine of County of Primorje-Gorski kotar, Rijeka, Croatia \\ ${ }^{2}$ University of Rijeka School of Medicine, University Hospital Centre Rijeka, Rijeka, Croatia
}

The goal: Takotsubo cardiomyopathy is recognized as an important differential diagnosis of acute myocardial infarction. It is characterized by a transient systolic dysfunction of apical, mid or basal segments of the left ventricle with an absence of obstructive coronary artery disease. Despite a rapid onset and severity of symptoms, it is considered to be a relatively benign condition with swift resolution of symptoms and wall motion abnormalities, even though it may have complicated clinical course and lead to mortal outcome. Our aim was to present a patient under severe emotional stress in which the clinical course was complicated with an irreversible cardiogenic shock.

Patient and Methods: Single patient clinical characteristics are analysed using available medical record.

\section{Received: $20^{\text {th }}$ Apr 2014}

*Address for correspondence: Zavod za hitnu medicinu Primorsko-goranske županije, B. Blečića bb, HR-51000 Rijeka, Croatia.

Phone: +385-91-7328081

E-mail: skoruplea@gmail.com
Results: A 78-year-old woman was presented with signs and symptoms of acute heart failure. The ECG and laboratory findings lead to suspect on ST elevation myocardial infarction. Coronarography excluded the acute myocardial infarction and left ventriculography indicated takotsubo cardiomyopathy as a cause of the existing symptoms. Despite the intensive treatment, respiratory insufficiency and irreversible cardiogenic shock developed and in five days the patient succumbed to the illness.

Conclusion: Takotsubo cardiomyopathy has a benign clinical course in the most of the cases, which leads to a total recuperation of the systolic function and resolution of symptoms. Complications such as cardiogenic shock are rare. In this case we present a patient with irreversible cardiogenic shock as a rare complication of Takotsubo cardiomyopathy.

KEYWORDS: acute myocardial infarction, Takotsubo cardiomyopathy, severe emotional stress.

CITATION: Cardiol Croat. 2014;9(5-6):174.

\section{Literature}

1. Gianni M, Dentali F, Grandi AM, Sumner G, Hiralal R, Lonn E. Apical ballooning syndrome or takotsubo cardiomyopathy: a systematic review. Eur Heart J. 2006; $27: 1523-9$. 2. Akashi YJ, Goldstein DJ, Barbaro G, Ueyama T. Takotsubo cardiomyopathy: a new form of acute, reversible heart failure. Circulation. 2008;118:2754-62.

3. Kawai S, Suzuki H, Yamaguchi H, et al. Ampulla cardiomyopathy ('Takotsubo' cardiomyopathy)-reversible left ventricular dysfunction: with ST segment elevation. Jpn Circ J 2000;64:156-9. 